architecture, and the one supreme concern of the town-planner, invention has done less than in any department of material civilisation. Only in the matter of artificial lighting, and in sanitation, if in that, is the average house of to-day superior to the average house of two thousand years ago. In the matters of hot-water supply and plumber's worlz generally, of cooking apparatus, cleaning arrangements, heating, and ventilation, the modern house is a disgrace to a scientific age. What has been done for centuries towards the improvement of door and window mechanism? Even the external material of houses is the same as was used five or six thousand years ago, and is no more damp-proof now than it was then.

Take care of the houses and the town will take care of itself. Here is a work, of vital importance for the welfare of the race, which may well be the first care of those who apply the Act.

A. E. Crawley.

\section{THE MELANESIANS OF BRITISH NEW} GUINEA.²

I $\mathrm{N}$ this volume is presented for the first time an adequate account of the sociology of a portion of the people of British New Guinea. The material which it embodies was collected during two visits of the author to New Guinea, and he has been ably assisted by various members of the Government and of the missions resident in the island. 'The book is a conspicuous example of what may be achieved by expert inquiry combined with local knowledge.

Dr. Seligmann uses the term Papuasian to signify all the inhabitants of New Guinea and the adjacent archipelagoes. These form two distinct groups. For the taller, darker, and more frizzly-haired people of the west he retains the term Papuan. The smaller, lighter-coloured peoples of the eastern peninsula and islands, in which the true Melanesian element is dominant, are called Papuo-Melanesians. With these Dr. Seligmann deals in the present volume, the Papuans being only alluded to when their physical characteristics or customs refer to the subject of discussion. Following Dr. Haddon's suggestion in the "Decorative Art of New Guinea," the author divides the Papuo-Melanesian peoples into two main groups, the western Papuo-Melanesians and the Massim of the east.

An introduction gives a succinct account of the general sociology and culture of the two groups. These agree in certain physical and cultural characters, which clearly differentiate them from the Papuan, but differ in many respects from one another. The amount of variation among the western Papuo-Melanesians is much greater than that found among the Massim peoples. The greater uniformity of the latter is regarded by Dr. Seligmann as due to a geographical factor. The small islands and peninsulas of the eastern district afforded less shelter for fugitives than the swamps and forests of the west, so that the Melanesian conquest was there more rapid and complete. Owing also to the slower mingling of the Melanesians with the original populations of the west, Dr. Seligmann considers that there is not only a considerable Papuan element in their composition, but that they have also in some cases adopted Papuan languages differing from each other as do the Papuan languages spoken by Papuans. If the Papuan elements were sufficiently strong to impose their language upon their conquerors, they must have been sufficient to have imposed their customs, or, at least,

1 "The Melanesians of British New Guinea." By Dr. C. G. Seligmann, with a chapter by F. R. Barton, C.M.G., and an appendix by E. L. Giblin. Pp. xxiv + 766. (Cambridge: The University Press, 19ro.) 2Is. net.

NO. 2 I 38 , VOL. 84$]$ to have modified those which the invaders brought with them.

With the Motu of Port Moresby and the neighbourhood, who are the best known of the western PapuoMelanesians, the author associates the Koita. The latter speak a Papuan language, and have for generations inter-married with, and built their villages adjoining, the Motu. The fact that the Koita language shows no trace of Melanesian influence, and has names for indigenous plants and animals, which are unnamed by the Motu, presents a difficulty which Dr. Seligmann has not discussed. From the latter, too, they have adopted certain customs and arts. The Ikoro, Gaboni, and Sinaugolo tribes, which closely resemble the Motu, occupy the district inland from Kapakapa and the basin of the Kemp Welch River. All these people are distinguished by the use of the open ceremonial

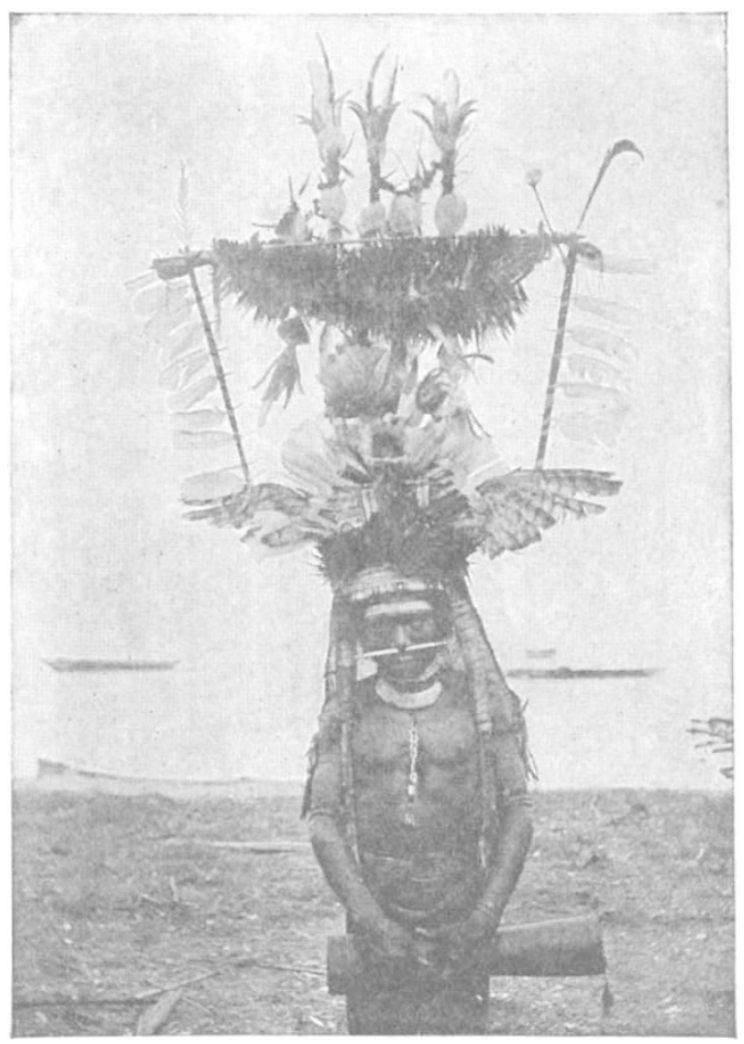

Copyright by the Rev. H. M. Dauncey.

FIG. 1.-Feather öaöa of the Rorc-speaking. Tribes. From "The Melanesians of British New Guinea."

platform, or dubu. Eastward from Hood Peninsula the coast is occupied by a rather different tribe, among whom the $d u b u$ gives place to the koge, or steeplehouse. All three groups have a general likeness in culture and sociology. There is a clan organisation and patrilinear descent. The first sixteen chapters of Dr. Seligmann's work deals in detail with the Koita regulation of public and family life, customs, trade, and religion, and includes an interesting account by Capt. F. R. Barton, of the Hiri or annual trading voyage made from Port Moresby to the Papuan Gulf. Another colony of Papuo-Melanesians (Mailu) dwelling around Milport Harbour and Port Glasgow, and speaking a Papuan language, are not discussed in detail by the author, neither are the Koiari and similar people of the hinterland, whom he regards as possessing more Melanesian than Papuan blood. 
The most western group of the immigrant Melanesians are the Roro and Mekeo people of the St. Joseph River, with whom are closely related the Pokao and Kapatsi between Hall Sound and Cape Suckling. In chapters xvii.-xxxi. the social relations and family life of the Roro are detailed, with an account of the clans and village organisation of the Mekeo, and a note on Pokao. This region is characterised by the greater importance attached to the right than to the left side in ceremonial matters, and by the prominence of geometrical design in the decorative art. Among the Mekeo there are traces of mother-right, though descent is patrilineal. A prominent feature in the

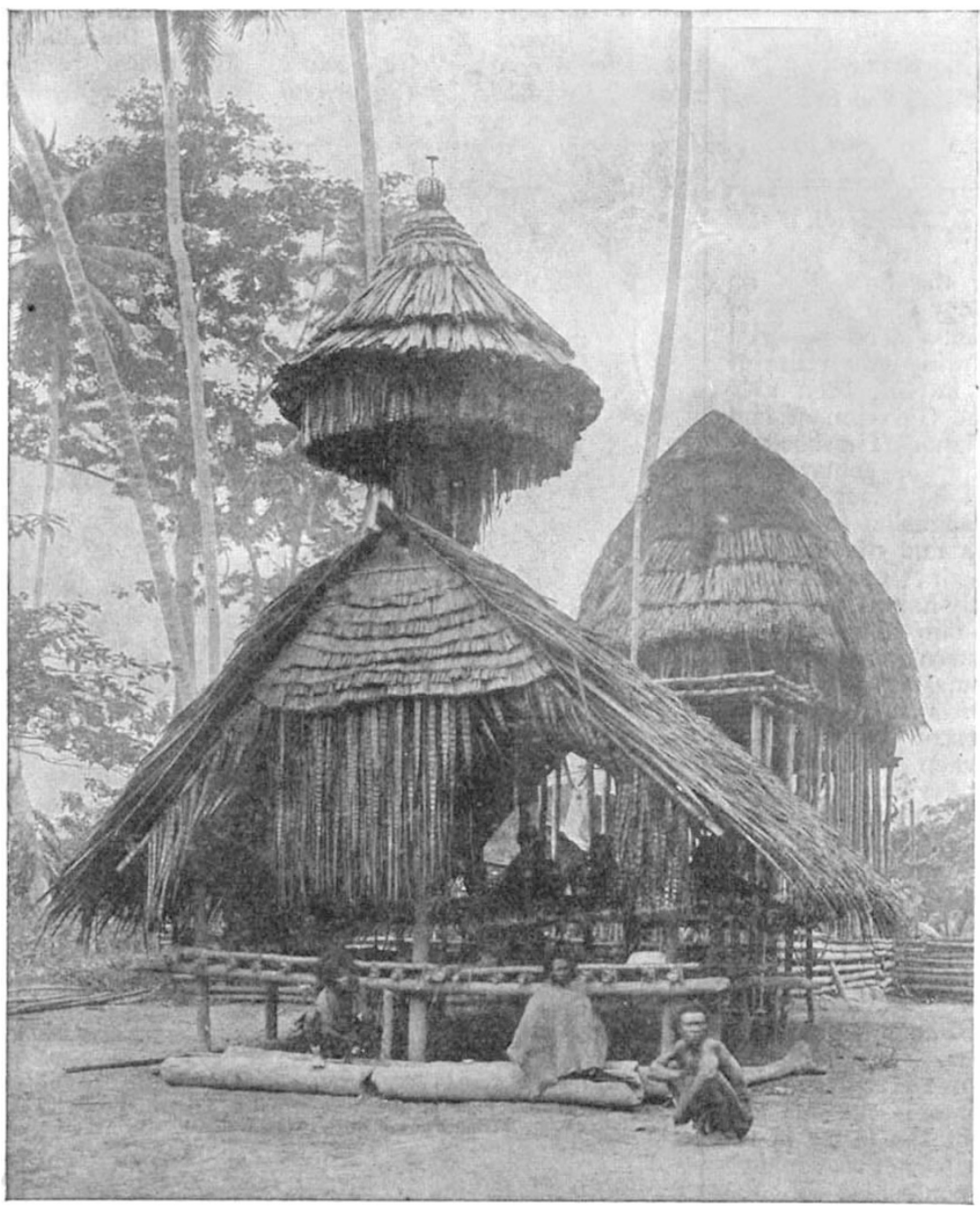

FIG. 2.-Popungapi ufu of Rarai Village. From "The Melanesians of British New Guinea,"

Mekeo village is the highly decorated $u f u$, or clubhouse.

The Massim people of the east are more homogeneous than the western Papuo-Melanesians. Dr. Seligmann makes two divisions, the northern in the Trobriands, Marshall-Bennet, Woodlark, Laughlan, and some smaller islands, the southern in the southeast peninsula of New Guinea between the south shore of Milne Bay and Goodenough Bay, with some of the Louisiades. Each division has its distinctive features. In the north there is a higher cephalic index and cranial capacity, a hereditary chieftainship, and NO. 2 I 38 , VOL. 84] absence of cannibalism. Both sections are remarkable for the building and use of large sea-going canoes, and the characteristic Massim decorative art reaches its highest development in the ornamental prows of these vessels in the north. The author's account of the sociology of the southern Massim includes a collection of folk-tales. The people live in hamletgroups, the inhabitants of which are more or less closely related by birth or marriage. There is also a peculiar form of totemism in which the members of a clan have as totems a series of associated animals or plants, as, e.g. a bird, fish, snake, and plant, the number and nature of these varying in different places.

The northern Massim are described in similar detail as regards the Trobriands, Marshall-Bennets, and Murua. Shorter accounts are given of the Louisiades and Mulsaua on the southern and western borders.

The volume is exceedingly well illustrated. There are seventy-nine plates from photographs or native drawings. Most of the former are exceptionally good. In addition there are fifty figures in the text drawn by Mr. Norman $H$. Hardy, a good map, a glossary of native words, and a very useful index. Dr. Seligmaniz has produced an interesting. trustworthy, and scholarly work on a most interesting section of the Melanesian people.

S. H. RAY.

\section{THE CENTENARY OF FILIPPO CAVOLINI.}

THE first centenary of the 1 death of Filippo Cavolini, the great Neapolitan naturalist, was celebrated on September 12-I3, the function having been arranged by the Society of Naturalists in Naples. Citizens, as well as the scientific and the political authorities, answered enthusiastically to the appeal of the society. The municipality and the University united, formed a powerful honorary general committee, the patronage of which was assumed by King Victor Emmanuel III. The chairman of the ordinary committee, composed of members of the Society of Naturalists, was the president of the society, Prof. F. S. Monticelli. The committee published an attractive booklet, giving a résumé of the life and works of $\mathrm{F}$. Cavolini.

On September I2 the aula magna of the University was thronged by delegates of the Italian and foreign universities, by members of the International Zoological Congress, and by others who had been invited. Amongst the many supporters, apart from the Italian Ministries of Public Instruction and of Agriculture we note those of many academies and universities of Europe and America, and also the Prince of Monaco.

Prof. Pasquale del Pezzo, rector of the University, 